\title{
Overwinter Storage of European Beech and Norway Spruce Planting Stock: Effect of Different Methods and Temperature Conditions
}

\author{
Petra Pantová *D, Kateřina Houšková (D) and Oldřich Mauer
}

check for updates

Citation: Pantová, P.; Houšková, K.; Mauer, O. Overwinter Storage of European Beech and Norway Spruce Planting Stock: Effect of Different Methods and Temperature Conditions. Forests 2021, 12, 1286. http://doi.org/10.3390/f12091286

Academic Editor: Holger Gärtner

Received: 18 August 2021

Accepted: 15 September 2021

Published: 19 September 2021

Publisher's Note: MDPI stays neutral with regard to jurisdictional claims in published maps and institutional affiliations.

Copyright: (c) 2021 by the authors. Licensee MDPI, Basel, Switzerland. This article is an open access article distributed under the terms and conditions of the Creative Commons Attribution (CC BY) license (https:/ / creativecommons.org/licenses/by/ $4.0 /)$.
Department of Silviculture, Faculty of Forestry and Wood Technology, Mendel University in Brno, Zemědělská 1, 61300 Brno, Czech Republic; katerina.houskova@mendelu.cz (K.H.); oldrich.mauer@mendelu.cz (O.M.)

* Correspondence: petra.pantova@mendelu.cz

\begin{abstract}
The aim of this research was to compare methods of overwinter storage of forest tree species planting stock and to specify of the optimal and the minimal temperature for freezing. Planting stock of European beech and Norway spruce were stored three times over a period of dormancy (2015/2016, 2016/2017, 2017/2018) (1) in freezers, (2) in an air-conditioned warehouse, (3) in a cave and (4) in soil (bare-rooted plants) and at a holding area (containerized plants), i.e., an open storage. During storage, the vitality of plants was determined using the root electrolyte leakage (REL) parameter, and in 2016 also by restoring growth in a sample of plants. The stored plants were always planted in a forest research plot in the spring and their basic morphological parameters and mortality were evaluated at the end of the growing season. The most suitable temperature for storage of both bare-rooted and containerized beech and spruce was in the range from $-3.4{ }^{\circ} \mathrm{C}$ to $-1.7^{\circ} \mathrm{C}$. The plants after overwinter storage showed no significant mortality after planting-they showed a high vitality of the fine roots and a normal increment, and were not damaged by frost, mold or other negative factors during storage.
\end{abstract}

Keywords: European beech; freezer storage; Norway spruce; overwinter storage; root electrolyte leakage

\section{Introduction}

Overwinter storage of planting material, i.e., its storage over one period of dormancy [1], is becoming an increasingly important and costly part of nursery production [2]. Planting stock is usually left over the winter in soil (bare-rooted plants) or at a holding area (containerized plants), and then lifted up and planted in the spring [3]. Due to climate change, the period for spring forestation is shortening, which, with the growing volume of forest nursery production and the time-consuming nature of spring work, leads not only to autumn forestation but also to the storage of planting material lifted up in autumn [4]. Prior to storage, the plants are prepared for dispatch from the nursery and placed under conditions designated for this purpose until the time of spring forestation.

In nursery practice, a common way of overwinter storing of containerized planting stock is to leave it on the holding area, while bare-rooted plants are usually left in soil (beds). The plants must be protected from frost [3]. Containerized plants are deposited on the surface of the holding area and the free sides are covered by strips of rubber [2]. Another possibility of eliminating the effect of frost is use of special packaging-Styrofoam [5] or overwintering of plants in natural snow or in artificial snow produced by snow cannons [6,7]. Bare-rooted plants are prepared for overwintering, i.e., they are released from bunches and the roots are covered with soil [3].

For overwinter storage of plants, appropriate spaces (e.g., caves, cellars) are places with a stable temperature of up to $+6{ }^{\circ} \mathrm{C}$ and relative humidity above $80 \%$ [8]. These conditions are provided by specially air-conditioned storage areas that allow storage of plants at temperatures from $0{ }^{\circ} \mathrm{C}$ to $+3{ }^{\circ} \mathrm{C}$ and at high relative humidity in the range of 
93\% to $98 \%$, depending on the method of protection of the seedlings against desiccation [9]. Storage of planting stock at temperatures above the freezing point, however, poses a risk of intensive development of fungi and mold on the stored plants [10]. In recent years, it has become standard operating procedure in many foreign nurseries, particularly in the countries of Northern Europe and North America [11,12], to store planting stock in freezers. Landis et al. [10] indicate that the planting material may be stored in a state of complete dormancy over the winter period in a freezer with a maintained air temperature of -2 to $-3{ }^{\circ} \mathrm{C}$. According to Ritchie [12], the freezing of planting stock is, in practice, limited to a period of 6-8 months. Luoranen et al. [13] states, however, that planting stock of Norway spruce can be safely frozen for $8-9$ months.

For overwinter storage in freezers, plants must be in complete dormancy and are therefore lifted up as late in the autumn as possible [14]. Dormant plants show the necessary frost resistance, which can also be supported by adjusting the temperature conditions before storage. It was found that acclimatization of planting stock in early September to October, with a temperature of $+1{ }^{\circ} \mathrm{C}$ to $+5^{\circ} \mathrm{C}$, accelerates the development of frost resistance and improves hardiness to freezing temperatures during storage. According to Němec [15] in Central Europe, dormant plants are suitable for storage when lifted up from mid-October to mid-March. Dormancy is determined by various methods, e.g., with the help of dormancy meters: calculating chilling sums or using the bud break test according to Landis et al. [3], and, for accurate verification of the date for storage of planting stock, it is possible to use the N-Sure method or the ColdNSure test [2].

During storage at freezing temperatures, it is necessary to control the air temperature and humidity [2]. The temperature should be measured not only in the storage space, but also inside the packaging because the plants are still respiring and the temperature in the bag or box may be a few degrees higher. Kooistra [11] stated that for this reason the temperature in the storage space should be $1-2{ }^{\circ} \mathrm{C}$ lower than desired temperature in the packaging that the plants are in. Radoglou, Raftoyannis [16] recommend a monthly inspection of the plants, particularly for possible frost damage. In addition, frost can cause desiccation, which Garriou et al. [17] pointed out.

When in overwinter storage, respiration and desiccation of plants must be reduced to a minimum, preferably by closing them in storage containers [2]. Indeed, Vitra [18] point out that overwinter storage in freezers can cause desiccation stress in the planting stock and a reduction in the supply of carbohydrates for maintaining its respiration. These physiological changes may cause a decline in chlorophyll fluorescence, which is directly related to photosynthetic activity and a slowdown in growth and a decline in the hardiness of seedlings after planting [19].

The working hypothesis of this research is that a storage temperature below $-3{ }^{\circ} \mathrm{C}$ can lead to an increase in the mortality and to a decrease in the vitality of fine roots, and it can affect the selected morphological parameters of European beech (Fagus sylvatica L.) and Norway spruce (Picea abies (L.) Karst) after planting. In addition, the aim of this research was (1) to specify a temperature limit for storage and (2) to compare various types of storage (a freezer, an air-conditioned warehouse, a cave and an open-storage).

\section{Materials and Methods}

For the purpose of this research (conducted in 2016-2018), both bare-rooted and containerized planting stock of European Beech and Norway Spruce were used (Table 1). Only in 2016, the bare-rooted European Beech was not tested because it was not possible to lift the planting stock from the soil due to the quick arrival of winter. The plants were grown according to standard procedures in the tree nursery LESCUS Cetkovice, s.r.o. (GPS 49.5762978N, 16.7301064E, Czech Republic). Planting stock was stored in different ways and under different conditions for three consecutive winters (2015/2016, 2016/2017, 2017/2018-in results marked 2016, 2017 and 2018, respectively, according to the year of outplanting). The storage of planting stock started on 17 February 2016, 5 December 2016 and 6 December 2017. The dates of storage were determined by the onset of dormancy of 
plants, identified by at least three methods: (a) the method of reaching the chilling sum of $500 \mathrm{~h}$ [20]; (b) determination of the water content in the terminal increment of plants [21] and (c) the $\mathrm{N}$-sure method or ColdNSure test [2].

Table 1. An overview of tested treatments of overwinter storage.

\begin{tabular}{|c|c|c|c|c|c|c|}
\hline Year of Planting & $\begin{array}{c}\text { Storage } \\
\text { Treatment }\end{array}$ & Species & $\begin{array}{c}\text { Type of Planting } \\
\text { Stock }\end{array}$ & Age of Plants & $\begin{array}{l}\text { Range of Height of } \\
\text { Above-Ground Part }\end{array}$ & Storage Duration \\
\hline \multirow{3}{*}{2016} & $-8^{\circ} \mathrm{C}$ & \multirow{3}{*}{$\begin{array}{l}\text { Spruce } \\
\text { Beech }\end{array}$} & Bare-rooted & 4 years & $26-35 \mathrm{~cm}$ & \multirow{3}{*}{61 days } \\
\hline & $-6^{\circ} \mathrm{C}$ & & Containerized & 2 years & $26-35 \mathrm{~cm}$ & \\
\hline & $-3^{\circ} \mathrm{C}$ & & Containerized & 1 year & $36-50 \mathrm{~cm}$ & \\
\hline \multirow{4}{*}{2017} & $-7^{\circ} \mathrm{C}$ & \multirow[b]{2}{*}{ Spruce } & Bare-rooted & 4 years & $36-50 \mathrm{~cm}$ & \multirow{4}{*}{119 days } \\
\hline & $-3{ }^{\circ} \mathrm{C}$ & & Containerized & 2 years & $26-35 \mathrm{~cm}$ & \\
\hline & $+2{ }^{\circ} \mathrm{C}$ & \multirow[b]{2}{*}{ Beech } & Bare-rooted & 2 years & $26-35 \mathrm{~cm}$ & \\
\hline & Open storage & & Containerized & 1 year & $36-50 \mathrm{~cm}$ & \\
\hline \multirow{4}{*}{2018} & $-8^{\circ} \mathrm{C}$ & \multirow{3}{*}{ Spruce } & Bare-rooted & 4 years & $26-35 \mathrm{~cm}$ & \multirow{4}{*}{135 days } \\
\hline & $-6^{\circ} \mathrm{C}$ & & Containerized & 2 years & $26-35 \mathrm{~cm}$ & \\
\hline & $-3^{\circ} \mathrm{C}$ & & Bare-rooted & 2 years & $26-35 \mathrm{~cm}$ & \\
\hline & $\begin{array}{c}\text { Cave } \\
\text { Open storage }\end{array}$ & Beech & Containerized & 1 year & $26-35 \mathrm{~cm}$ & \\
\hline
\end{tabular}

For overwinter storage of plants, three freezers were used, where the temperatures were set to $-1{ }^{\circ} \mathrm{C},-3{ }^{\circ} \mathrm{C},-6{ }^{\circ} \mathrm{C},-7{ }^{\circ} \mathrm{C}$ and $-8{ }^{\circ} \mathrm{C}$. Each year, 3 storage temperatures were selected and compared. Planting stock (bare-rooted and containerized after removal from the containers) was placed in small polyethylene bags (protecting the root system or root balls), then in large polyethylene bags (protecting the entire plants) and then in freezers. During the winter of 2016-2017, part of the planting stock was left in bundles (bare-rooted plants) or in groups with root balls wrapped in foil (containerized plants) and placed inside crates in air-conditioned warehouse at a temperature of $+2{ }^{\circ} \mathrm{C}(100 \%$ relative humidity). Norway Spruce planting stock (bare-rooted and containerized) was treated with Dithane (Dow AgroSciences s.r.o.) fungicide-once before and once during storage. In order to determine whether the planting stock can survive a winter inside non-air-conditioned spaces, we placed it inside in a cave on the territory of the Training Forest Enterprise Krrtiny of the Mendel University in Brno in2017/2018 winter. Bare-rooted plants were left in bundles, root balls of containerized plants were covered with foil. This cave was chosen for its stable temperature $\left(+4^{\circ} \mathrm{C}\right)$ and relative humidity $(\sim 100 \%)$. Another treatment of overwinter storage that we tested was open storage of containerized planting stock in inside containers at the holding area (laying the containers on the surface of the field and covering them on the free sides with strips of rubber) and placing the bare-rooted plants in a bed (lower parts of plants were placed in a bed and covered them with soil to a height of $10 \mathrm{~cm}$ above the root collar). An overview of tested treatments is shown in Table 1, where the treatments of frozen planting stock are labelled with the set temperatures (Note: The Discussion and Conclusion sections below deal with the measured temperatures).

During storage, the air temperature and humidity were monitored (sensor Minikin Thi) and in the years 2017 and 2018 these parameters were also determined directly inside the packaging of the plants in the freezers. The vitality of the fine roots of the plants of all treatments was checked for possible damage during the storage (21 March 2016, 14 February 2017, 6 March 2018) by means of the root electrolyte leakage (REL) parameter [22]. Low values of this parameter mean high survival. For each stored treatment, the REL was determined on the fine-root samples of 6 plants. In addition, in 2016 after about 1 month of storage (22 March 2016), 9 plants of each treatment were taken out of the freezers, acclimatized for approx. $24 \mathrm{~h}$ at approx. $5{ }^{\circ} \mathrm{C}$ and then planted in a bed at the nursery with regular irrigation for a general assessment of viability. Two months after planting, these sprouting plants were counted and at the end of the growing season the overall mortality was evaluated. 
After completion of the overwinter storage and acclimatization, all stored plants, i.e., 30 pcs of each treatment, were planted in the research plot with conditions corresponding to those of a fertile site of medium altitudes (GPS 49.5779817N, 16.7446072E, Czech Republic). At the end of the growing season the mortality was assessed and morphological parameters (height, root collar diameter and height increment) of the surviving plants were measured.

For statistical evaluation of the measured and determined parameters, the data was imported into Statistica ${ }^{\mathrm{TM}}$ 12.0. The Shapiro-Wilk test was applied in order to determine whether the data has a normal distribution. For comparison of normally distributed data sets, a one-way ANOVA $(\alpha=0.05)$ was applied. When the data was not of a normal distribution, the non-parametric Kruskal-Wallis test $(\alpha=0.05)$ was used.

\section{Results}

The Air Conditions during the Storage Treatment

Figures 1-3 show the course of the air temperatures in the storage places. It is evident from the graphs that the actual air temperatures differed slightly from the temperatures set in the freezers and the air-conditioned storage areas, and fluctuated within $\pm 0.5^{\circ} \mathrm{C}$. The ambient temperature (inside the bags) was 0.3 -to- $0.5^{\circ} \mathrm{C}$ higher than the set temperature in the freezers. The values of relative humidity measured in the freezers approached $\sim 100 \%$; in the air-conditioned storage, the relative humidity was $100 \%$ and, in the cave, it ranged from $65 \%$ to $70 \%$. The average relative humidity during overwintering of the planting stock in the tree nursery (i.e., open storage) was $89 \%$.

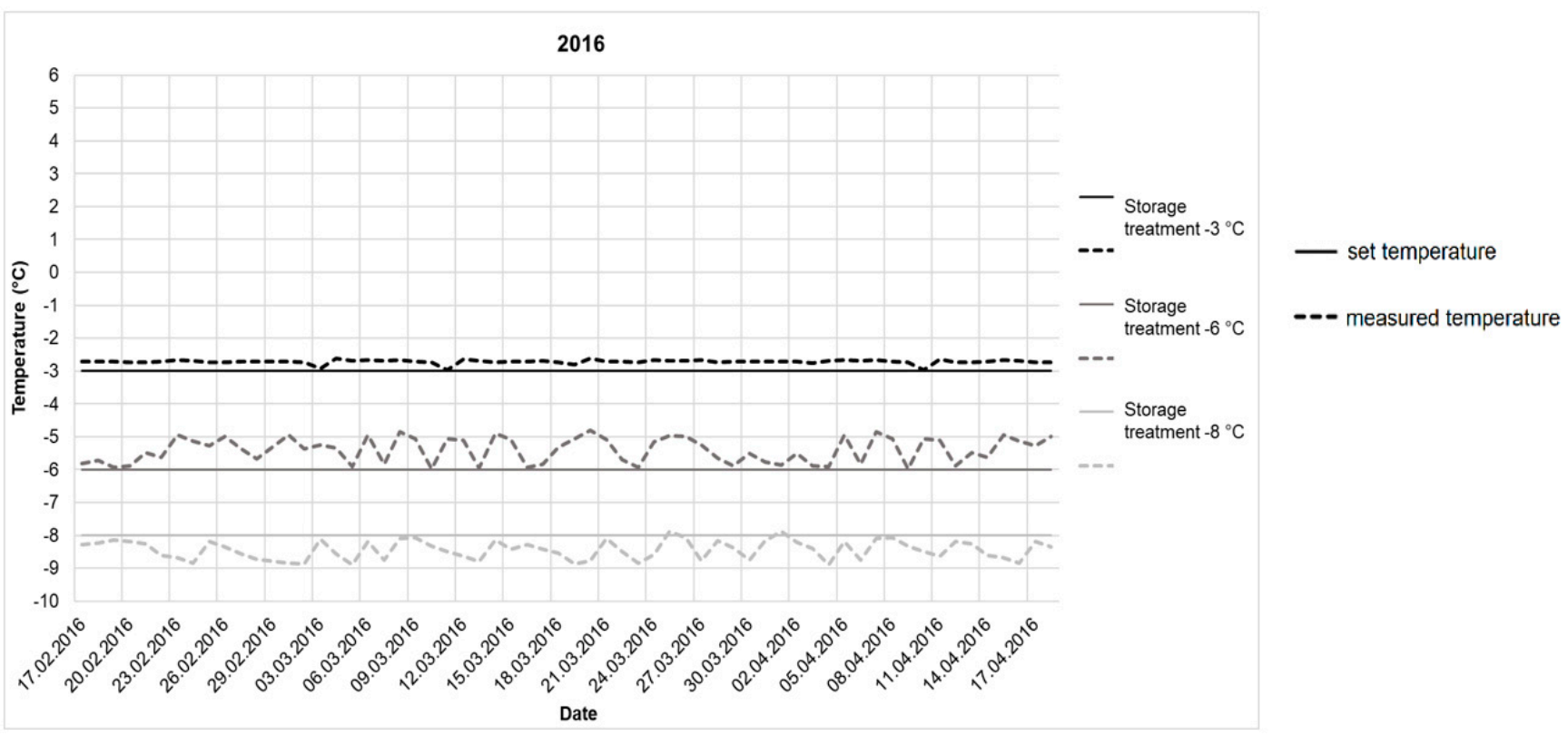

Figure 1. Air temperature during storage of the tested plants in 2016. 


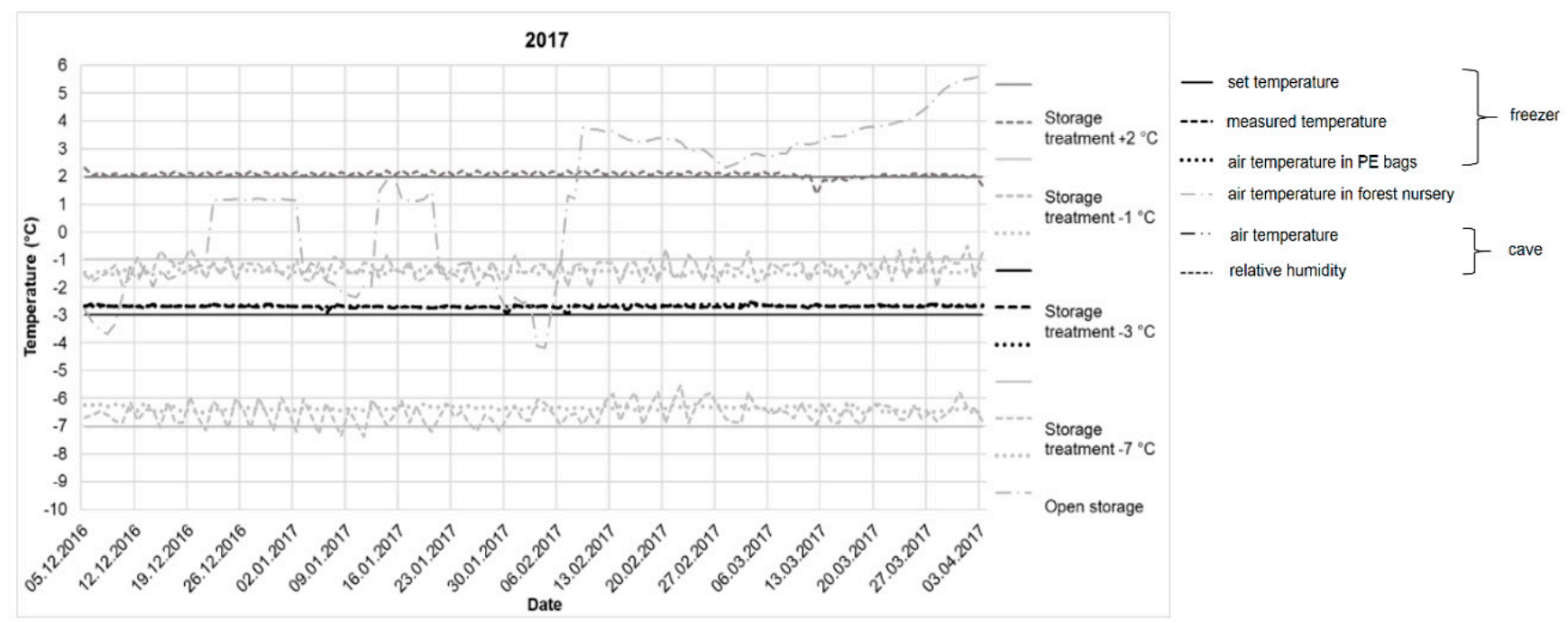

Figure 2. Air temperature during storage of the tested plants in 2017.

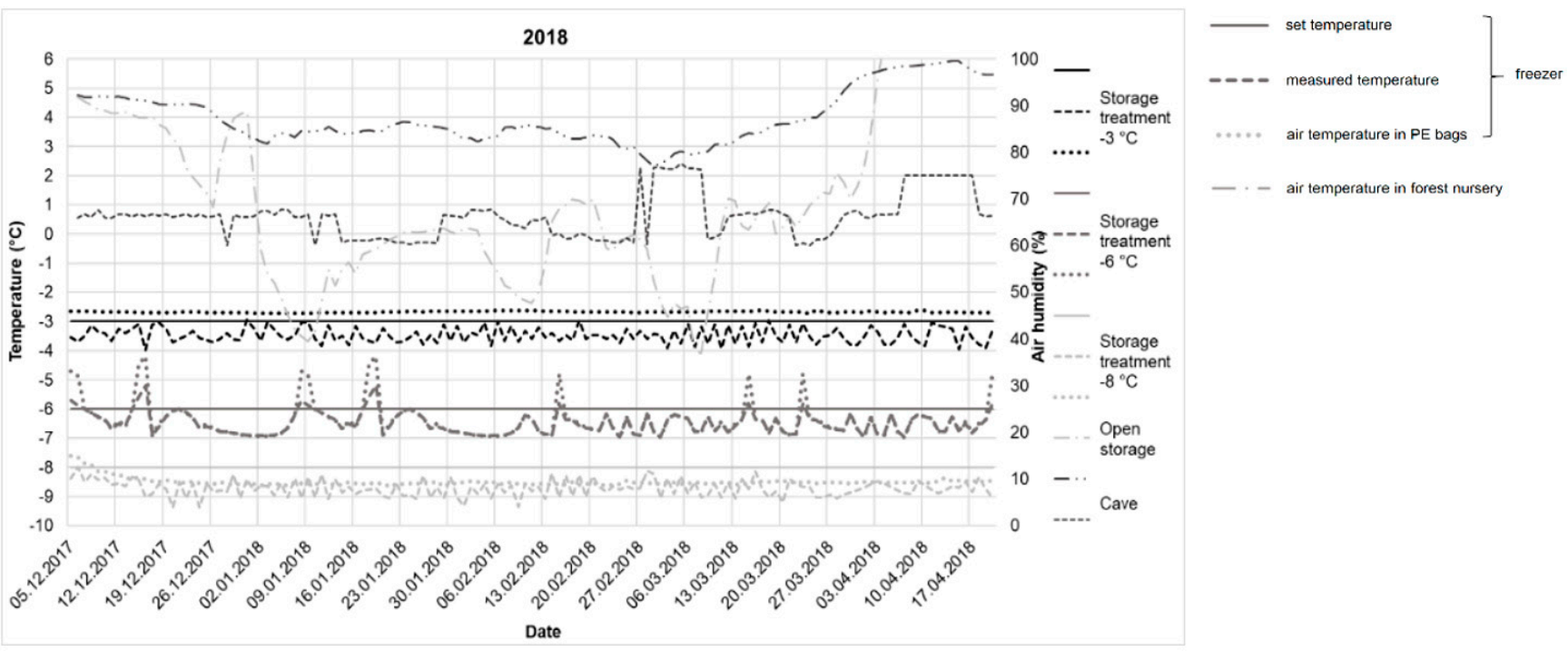

Figure 3. Air temperature during storage of the tested plants in 2018.

For bare-rooted spruce, the vitality of the fine roots decreased (and the REL increased) with each decrease in storage temperature (Figure 4). The treatments of the plants stored at $-3{ }^{\circ} \mathrm{C}$ to $+2{ }^{\circ} \mathrm{C}$ had a REL of the fine roots of up to $50 \%$, the bare-rooted spruce stored at $-6{ }^{\circ} \mathrm{C}$ showed a REL of about $50 \%$. A higher REL (approx. 55\%) was found in the fine roots of the treatments stored at $-7^{\circ} \mathrm{C}$ and on the spruce in the bed (i.e., open storage). A lower vitality of the fine roots (i.e., a higher REL) was found in spruces stored at $-8{ }^{\circ} \mathrm{C}$ and the plants stored in the cave had the lowest vitality of the fine roots. However, the spruce stored in the air-conditioned warehouse at $+2{ }^{\circ} \mathrm{C}$ was visibly infested with mold (because of the air temperature above $0{ }^{\circ} \mathrm{C}$ and the high relative humidity, which is suitable for mold development), both in the bare-rooted and containerized treatments. 

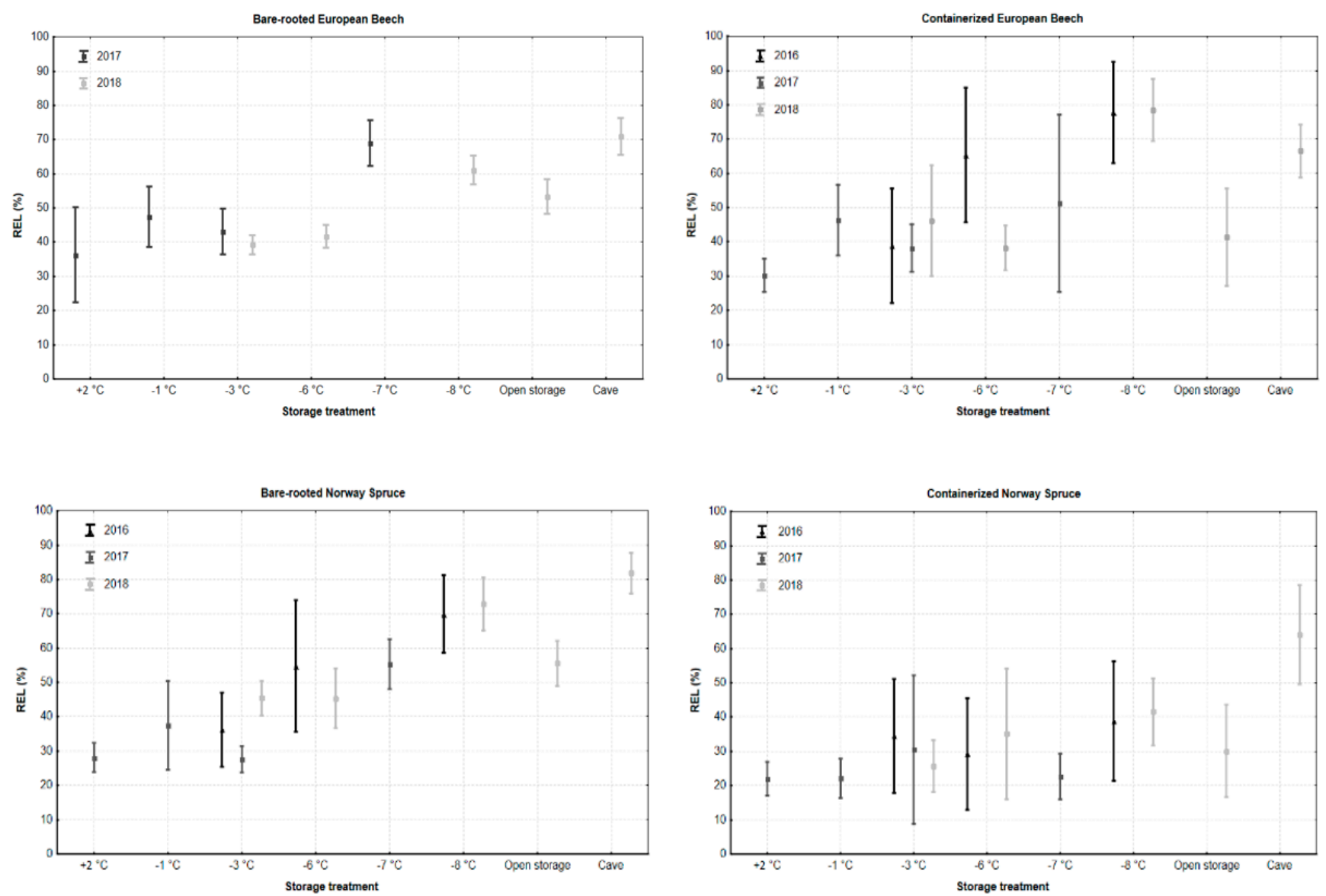

Figure 4. Root Electrolyte Leakage, approx. in the middle of the storage period of the bare-rooted and containerized European beech and Norway spruce plants in the various storage treatments in the three years of the research (low REL relates to higher plant viability).

Containerized spruces exhibited a higher vitality of fine roots in the storage treatments of $-3{ }^{\circ} \mathrm{C}$ to $+2{ }^{\circ} \mathrm{C}$, similarly to bare-rooted spruce (Figure 4 ). However, during storage at lower temperatures $\left(-6^{\circ} \mathrm{C},-7{ }^{\circ} \mathrm{C},-8^{\circ} \mathrm{C}\right)$ and during open storage, the vitality of the fine roots did not decrease and the REL was comparable to that of the treatments of the plants stored at higher temperatures. Statistically, the lowest vitality of fine roots (highest REL) was found in plants stored in the cave (approx. 65\%).

Bare-rooted beech at a storage temperature of above $-6^{\circ} \mathrm{C}$ had a REL of about $50 \%$, similar to that of spruce (Figure 4). At storage temperatures of $-7^{\circ} \mathrm{C}$ to $-8{ }^{\circ} \mathrm{C}$, REL was statistically significantly higher (always above 55\%) and the average value of REL of the plants stored in the open was 55\%. The lowest vitality of the fine roots was observed on the bare-rooted beeches stored in the cave (above 65\%).

The highest vitality of the fine roots (i.e., the lowest REL of approx. 30\%) was found in the containerized beeches stored in the air-conditioned storage at $+2{ }^{\circ} \mathrm{C}$ (Figure 4 ). When storing the planting stock at temperatures of $-1{ }^{\circ} \mathrm{C}$ and $-3{ }^{\circ} \mathrm{C}$, the REL usually reached $50 \%$. At lower storage temperatures, in some treatments, the REL values were found to be above $50 \%$ and, statistically, the plants reached the highest REL when stored at $-8{ }^{\circ} \mathrm{C}$ (approx. 80\%). Containerized beech in open storage showed a REL of up to $50 \%$ and the plants stored in the cave had a high REL. Containerized beech proved to have a lower vitality of the fine roots in most of the tested treatments than containerized spruce, but the bare-rooted beech had a higher vitality when stored at a temperature of $-7^{\circ} \mathrm{C}$ in the open and in the cave.

Monitoring of plants during freezing storage (after one month of storage) show that most of the plants resumed growth in all treatments stored in freezers $(100 \%$ of sprouting 
plants), with the exception of containerized beech and bare-rooted spruce stored at $-8^{\circ} \mathrm{C}$ (Table 2). The results at the beginning of the growing season were confirmed by mortality at the end. After overwinter storage at low temperatures $\left(-8^{\circ} \mathrm{C}\right)$, the mortality observed in both bare-rooted spruce and containerized beech was 100\%. The plants which were stored for 1 month at $-3{ }^{\circ} \mathrm{C}$ and $-6{ }^{\circ} \mathrm{C}$ were all still alive, as was the containerized spruce (mortality $0 \%$ ).

Table 2. The number of sprouting plants after planting and mortality at the end of the growing season planted to check plant viability during storage.

\begin{tabular}{|c|c|c|c|c|c|c|c|}
\hline \multirow{3}{*}{$\begin{array}{l}\text { Woody } \\
\text { Species }\end{array}$} & \multirow{3}{*}{$\begin{array}{l}\text { Type of } \\
\text { Planting } \\
\text { Stock }\end{array}$} & \multicolumn{6}{|c|}{ Storage Treatment } \\
\hline & & \multicolumn{2}{|c|}{$-3^{\circ} \mathrm{C}$} & \multicolumn{2}{|c|}{$-6^{\circ} \mathrm{C}$} & \multicolumn{2}{|c|}{$-8^{\circ} \mathrm{C}$} \\
\hline & & $\begin{array}{l}\text { Number of } \\
\text { Sprouting } \\
\text { Plants (\%) }\end{array}$ & $\begin{array}{c}\text { Mortality } \\
(\%)\end{array}$ & $\begin{array}{l}\text { Number of } \\
\text { Sprouting } \\
\text { Plants (\%) }\end{array}$ & $\begin{array}{c}\text { Mortality } \\
(\%)\end{array}$ & $\begin{array}{l}\text { Number of } \\
\text { Sprouting } \\
\text { Plants (\%) }\end{array}$ & $\begin{array}{c}\text { Mortality } \\
(\%)\end{array}$ \\
\hline \multirow{2}{*}{ Spruce } & Bare-rooted & 100 & 0 & 100 & 0 & 0 & 100 \\
\hline & Containerized & 100 & 0 & 100 & 0 & 100 & 0 \\
\hline Beech & Containerized & 100 & 0 & 100 & 0 & 0 & 100 \\
\hline
\end{tabular}

Immediately after storage, the spruces from the air-conditioned warehouse were infested with mold, but this infection was not found at the end of the growing season. In addition, the lowest mortality $(0 \%)$ was found in all years of testing after storage of the bare-rooted and containerized spruces in the air-conditioned storage and in the freezer with a temperature of $-1{ }^{\circ} \mathrm{C}$ (Figure 5). Acceptable mortality (up to $10 \%$ ) was usually found on the open-storage spruces and during storage temperatures of $-3^{\circ} \mathrm{C}$. Storage of plants at the temperature of $-8{ }^{\circ} \mathrm{C}$ and in the cave led to very high mortality (above $50 \%$ ).
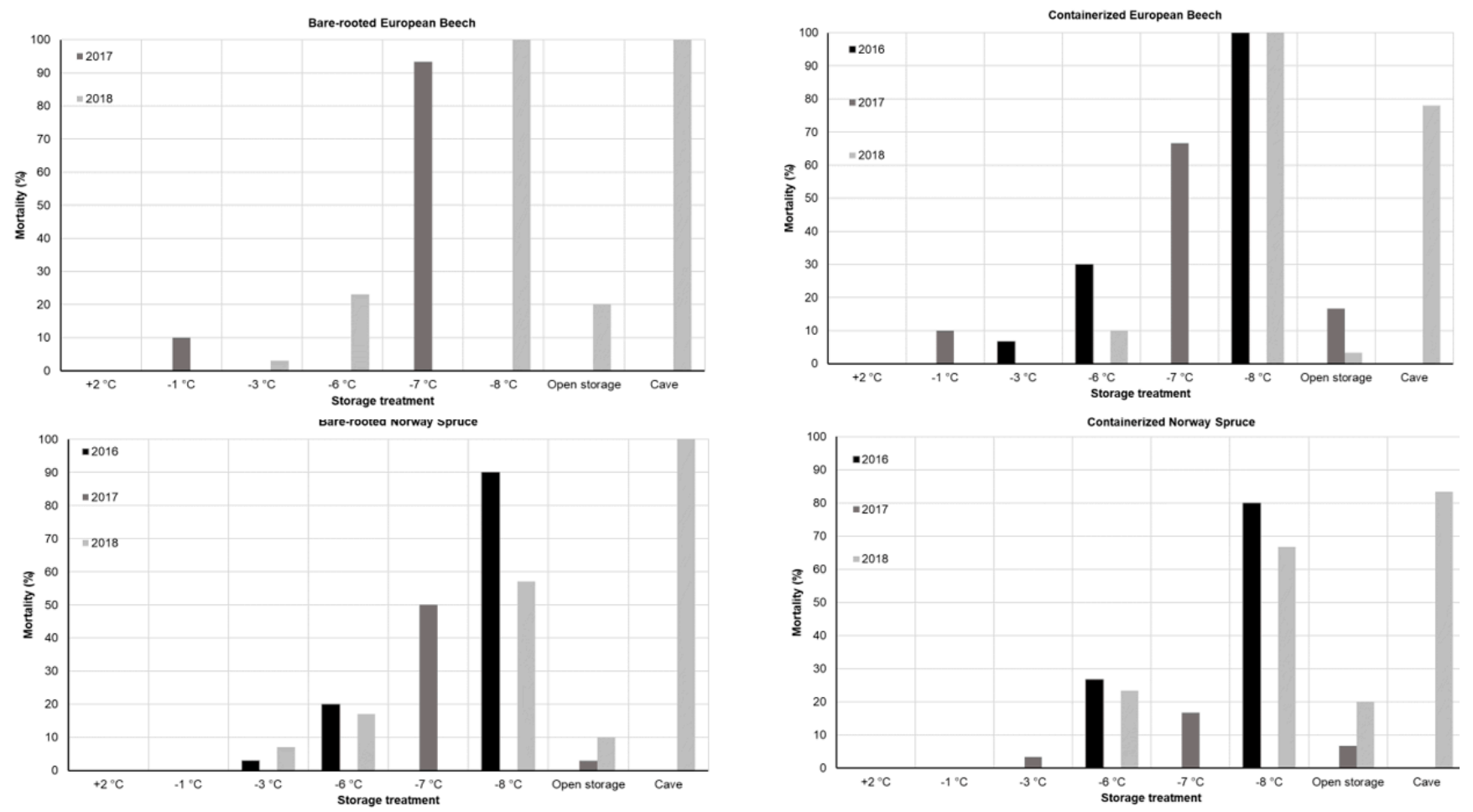

Figure 5. Mortality of the bare-rooted and containerized European beech and Norway spruce plants in the various storage treatments at the end of the first growing season in three years of the research. 
Acceptable mortality of beech (of up to $10 \%$ ) was recorded after storage at $+2{ }^{\circ} \mathrm{C}$ to $-3{ }^{\circ} \mathrm{C}$ (Figure 5). A mortality of up to $20 \%$ was recorded in the beeches from the open storage and the storage field. We observed that after storage at the temperatures of $-7{ }^{\circ} \mathrm{C}$ and $-8{ }^{\circ} \mathrm{C}$ and after storage in the cave, mortality of plants was very high (above $50 \%$ ).

Statistically significant differences in the heights of the plants at the end of the growing season were found between the different types of storage treatment (Table 3). It is not possible to clearly determine which plants were tallest and which were shortest because the results for the different types of planting stock in the individual years differed. The effect of high initial variability in plant heights is evident here (i.e., the wide range of the heights of the planting stock). Usually, only some of the tallest plants survived the storage at $-8{ }^{\circ} \mathrm{C}$.

Table 3. Average height of Norway spruce and European beech in storage treatments at the end of the first growing season in three years of the research (different letters in the exponent $(a, b, c)$ denote significant differences between storage treatments within each tree species and type of planting stock in every year of the research).

\begin{tabular}{|c|c|c|c|c|c|c|c|c|c|c|c|c|c|c|}
\hline \multirow{4}{*}{ Species } & \multirow{4}{*}{ Type of Planting Stock } & \multicolumn{13}{|c|}{ Height of Plants $(\mathrm{cm})$ in } \\
\hline & & \multicolumn{3}{|c|}{2016} & \multicolumn{5}{|c|}{2017} & \multicolumn{5}{|c|}{2018} \\
\hline & & \multicolumn{13}{|c|}{ Storage Treatment } \\
\hline & & $-8^{\circ} \mathrm{C}$ & $-6^{\circ} \mathrm{C}$ & $-3^{\circ} \mathrm{C}$ & $-7^{\circ} \mathrm{C}$ & $-3^{\circ} \mathrm{C}$ & $-1^{\circ} \mathrm{C}$ & $+2{ }^{\circ} \mathrm{C}$ & $\begin{array}{c}\text { Open } \\
\text { Storage }\end{array}$ & $-8^{\circ} \mathrm{C}$ & $-6^{\circ} \mathrm{C}$ & $-3{ }^{\circ} \mathrm{C}$ & Cave & $\begin{array}{c}\text { Open } \\
\text { Storage }\end{array}$ \\
\hline \multirow{2}{*}{ Spruce } & Bare-rooted & $40.0^{\mathrm{a}}$ & $32.8^{\mathrm{c}}$ & $37.3^{b}$ & $45.4^{\mathrm{c}}$ & $52.6^{\mathrm{b}}$ & $44.1^{\mathrm{d}}$ & $62.0^{\mathrm{a}}$ & $46.6^{c}$ & $24.5^{\mathrm{d}}$ & $27.3^{c}$ & $29.2 \mathrm{~b}$ & $----^{*}$ & $31.1^{\mathrm{a}}$ \\
\hline & Containerized & $35.1 \mathrm{~b}$ & $37.0^{\mathrm{a}}$ & $34.0^{\mathrm{b}}$ & $43.2^{\mathrm{a}}$ & $43.6^{\mathrm{a}}$ & $41.2^{\mathrm{b}}$ & $41.5^{b}$ & $34.9^{\mathrm{c}}$ & $45.3^{\mathrm{a}}$ & $41.4^{\mathrm{b}}$ & $36.3^{\mathrm{d}}$ & $38.3^{\mathrm{c}}$ & $38.3^{\mathrm{C}}$ \\
\hline \multirow{2}{*}{ Beech } & Bare-rooted & & & & $30.0^{\mathrm{c}}$ & $44.2^{\mathrm{a}}$ & $44.0^{\mathrm{a}}$ & $39.2 \mathrm{~b}$ & $45.5^{\mathrm{a}}$ & $----^{*}$ & $38.3^{\mathrm{a}}$ & $38.8^{\mathrm{a}}$ & $----^{*}$ & $34.9^{\mathrm{b}}$ \\
\hline & Containerized & $----^{*}$ & $32.0^{\mathrm{a}}$ & $40.0^{\mathrm{a}}$ & $46.2^{\mathrm{a}}$ & $47.2^{\mathrm{a}}$ & $40.3^{b}$ & $45.2^{\mathrm{a}}$ & $39.3^{\mathrm{c}}$ & $----^{*}$ & $37.0^{\mathrm{a}}$ & $31.5^{\mathrm{b}}$ & $38.2^{\mathrm{a}}$ & $32.4 \mathrm{~b}$ \\
\hline
\end{tabular}

* Parameter not detected-plants were dead.

The results in Table 4 show that the root collars of the beeches, which were stored at $-3{ }^{\circ} \mathrm{C}$, were thicker. Thicker root collars were also found in the bare-rooted spruces that were stored at $+2{ }^{\circ} \mathrm{C}$ and in the treatments in the open storage. Regarding the containerized spruces, only the plants with a thicker root collar often survived storage at -7 and $-8{ }^{\circ} \mathrm{C}$.

Table 4. Average root collar diameters of Norway spruce and European beech in storage treatments at the end of the first growing season in three years of the research (different letters in the exponent ( $a, b, c)$ denote significant differences between storage treatments within each tree species and type of planting stock in every year of the research).

\begin{tabular}{|c|c|c|c|c|c|c|c|c|c|c|c|c|c|c|}
\hline \multirow{3}{*}{ Species } & \multirow{3}{*}{ Type of Planting Stock } & \multicolumn{13}{|c|}{ Root Collar Diameter $(\mathrm{mm})$ in } \\
\hline & & \multicolumn{3}{|c|}{2016} & \multicolumn{5}{|c|}{2017} & \multicolumn{5}{|c|}{2018} \\
\hline & & $-8^{\circ} \mathrm{C}$ & $-6^{\circ} \mathrm{C}$ & $-3^{\circ} \mathrm{C}$ & $-7^{\circ} \mathrm{C}$ & $-3^{\circ} \mathrm{C}$ & $-1{ }^{\circ} \mathrm{C}$ & $+2{ }^{\circ} \mathrm{C}$ & $\begin{array}{c}\text { Open } \\
\text { Storage }\end{array}$ & $-8^{\circ} \mathrm{C}$ & $-6^{\circ} \mathrm{C}$ & $-3^{\circ} \mathrm{C}$ & Cave & $\begin{array}{c}\text { Open } \\
\text { Storage } \\
\end{array}$ \\
\hline \multirow{2}{*}{ Spruce } & Bare-rooted & $7.0^{\mathrm{b}}$ & $7.9^{\mathrm{a}}$ & $7.7^{\mathrm{a}}$ & $6.7^{\mathrm{d}}$ & $7.9^{\mathrm{c}}$ & $8.3^{b}$ & $9.4^{\mathrm{a}}$ & $8.8^{\mathrm{b}}$ & $6.5^{\mathrm{a}}$ & $6.1^{\mathrm{a}}$ & $6.7^{\mathrm{a}}$ & $----^{*}$ & $6.9^{\mathrm{a}}$ \\
\hline & Containerized & $7.4^{\mathrm{a}}$ & $6.7^{\mathrm{b}}$ & $6.8^{\mathrm{b}}$ & $7.1^{\mathrm{a}}$ & $7.2^{\mathrm{a}}$ & $7.4^{\mathrm{a}}$ & $7.4^{\mathrm{a}}$ & $7.1^{\mathrm{a}}$ & $7.6^{\mathrm{b}}$ & $7.5^{\mathrm{b}}$ & $8.2^{\mathrm{a}}$ & $7.6^{b}$ & $6.4^{c}$ \\
\hline \multirow{2}{*}{ Beech } & Bare-rooted & & & & $7.7^{\mathrm{b}}$ & $8.8^{\mathrm{a}}$ & $7.7 \mathrm{~b}$ & $6.8^{\mathrm{b}}$ & $7.7 \mathrm{~b}$ & $----^{*}$ & $6.0^{\mathrm{a}}$ & $6.7^{\mathrm{a}}$ & $----^{*}$ & $6.0^{\mathrm{a}}$ \\
\hline & Containerized & $----^{*}$ & $6.3^{\mathrm{a}}$ & $6.8^{\mathrm{a}}$ & $6.2^{\mathrm{b}}$ & $7.0^{\mathrm{a}}$ & $6.8^{\mathrm{b}}$ & $6.4^{\mathrm{a}}$ & $6.4^{\mathrm{b}}$ & $5.2^{\mathrm{b}}$ & $5.6^{\mathrm{b}}$ & $8.1^{\mathrm{a}}$ & $5.8^{\mathrm{b}}$ & $5.5^{\mathrm{b}}$ \\
\hline
\end{tabular}

* Parameter not detected-plants were dead.

The highest increments were usually achieved by plants after storage at $-3{ }^{\circ} \mathrm{C}$ (Figure 6). A comparable increment was found for spruce stored at $-1{ }^{\circ} \mathrm{C}(12 \mathrm{~cm})$ and $+2{ }^{\circ} \mathrm{C}(11 \mathrm{~cm})$. A storage temperature of $-6^{\circ} \mathrm{C}$ often caused a shorter increment in barerooted planting stock after planting; the increment of containerized planting stock was comparable to that of the plants stored at higher temperatures. Containerized spruce stored at a temperature of $-7^{\circ} \mathrm{C}$ showed a comparable increment, as did the plants stored at $-6{ }^{\circ} \mathrm{C}$ and partly at $-3{ }^{\circ} \mathrm{C}$. Other plants after storage at -7 and $-8{ }^{\circ} \mathrm{C}$ showed only a minimal increment and the plants stored in the cave showed no increment at all. The plants from open storage, aside from containerized beech, did not achieve a higher increment on the tallest plants. 

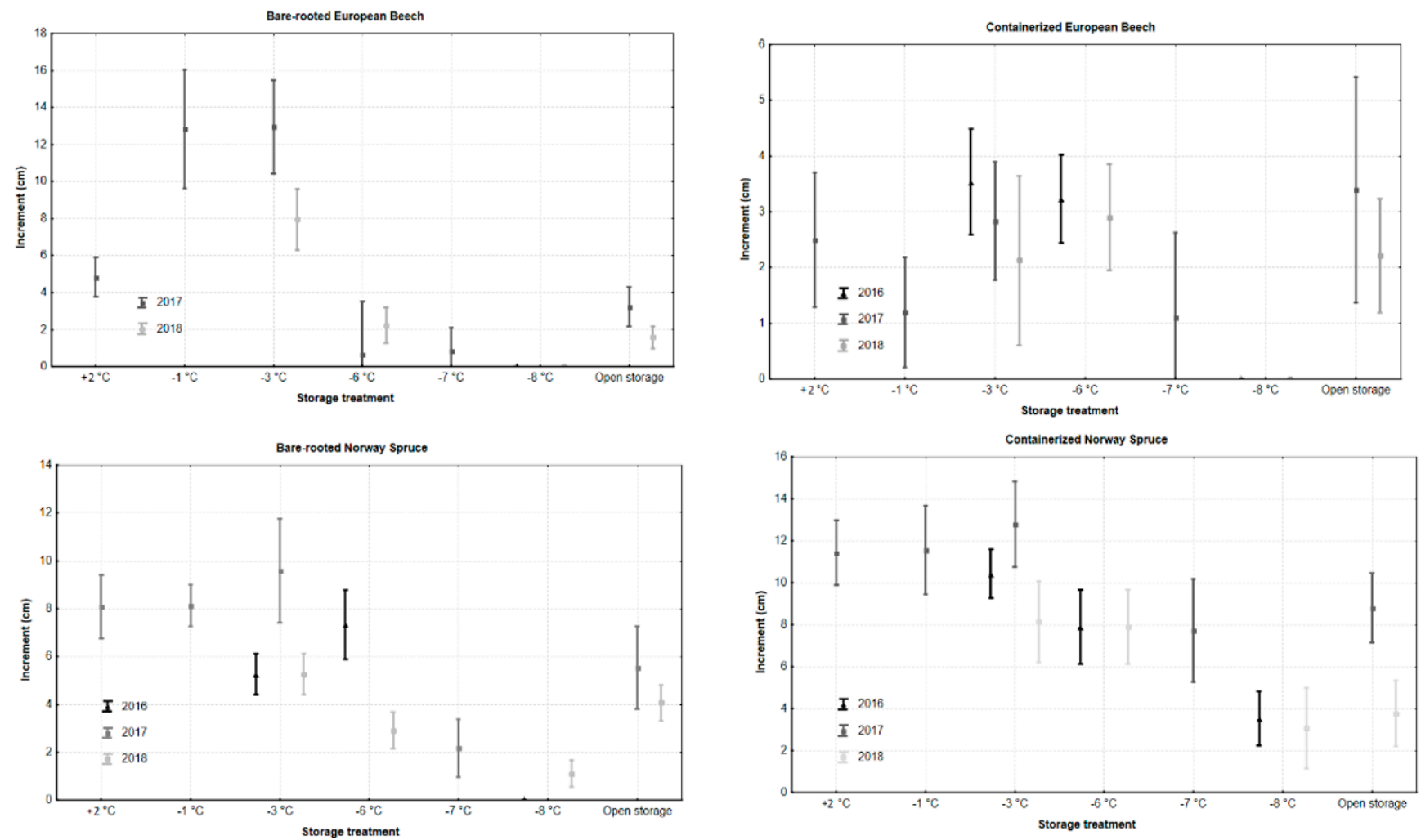

Figure 6. Height increment of the bare-rooted and containerized European beech and Norway spruce plants in various storage treatments at the end of the first growing season in three years of the research.

\section{Discussion}

Overwinter storage of planting stock has become a normal part of growing technology in many tree nurseries. Use of the latest method-the storing of plants in freezers-will undoubtedly continue to rise. Fundamental to its successful use is the choice of optimal storage temperature and the regular monitoring of plants.

Plants intended for storage at freezing temperatures must be in a state of complete dormancy [3]. Janda et al. [23] indicates that, at the onset of dormancy in plants, there is a gradual accumulation of carbohydrates and other osmotically active substances. In addition, the amount of water in the plant cells decreases, which leads to division of the central vacuole [24]. Temperatures lower than $0{ }^{\circ} \mathrm{C}$ led to the formation of ice crystals both inside and outside the cells. If crystals form inside the cells, it leads to irreversible damage to the cell structures [25]. Conversely, ice generally forms outside (i.e., in the inter-cellular spaces) when the cells are exposed to temperatures of about $-1^{\circ} \mathrm{C}$ to $-3^{\circ} \mathrm{C}$. However, if the plants are not hardy, severe dehydration of the cell content and mechanical damage to the cell walls and plasma membranes can occur $[25,26]$.

REL, height increment and mortality of plants proved to be the best indicators of the plants' response to possible damage (frost damage and/or desiccation) during overwinter storage in the current research. The plant height and the root collar diameter were not affected by the higher initial variability and mortality (i.e., the smaller and weaker plants often died first). The results showed that both bare-rooted and containerized beeches and spruces grew best and achieved the lowest losses after storage at a temperature of $-3.4^{\circ} \mathrm{C}$ to $-1.7^{\circ} \mathrm{C}$ (measured directly on the plants inside the bag). In addition, Wesoly, Chabowska [27] confirm that freezing temperatures are better for the storage of planting stock, since there is the risk of fungal infestation at higher storage temperatures. Dumroese et al. [28] also indicate the most suitable storage temperature to be in the range of $-2{ }^{\circ} \mathrm{C}$ to $-4{ }^{\circ} \mathrm{C}$. Suitability of the storage temperature down to $-5^{\circ} \mathrm{C}$ was also proven in testing 
conducted by Repo [29]. In addition, it was confirmed that overwinter storage at $-5{ }^{\circ} \mathrm{C}$ does not affect the metabolic activity of mycorrhizal fungi.

In the current research, lower temperatures from $-6.6^{\circ} \mathrm{C}$ to $-8.4^{\circ} \mathrm{C}$ for storing both types of planting stock and for both woody species were inappropriate. The tested plants were found to have low vitality of fine roots (a high REL value), shorter increments and unacceptable mortality at the end of the growing season after planting. Wang, Zwiazek [30] also note that very low storage temperatures reduce the growth potential of roots and cause delayed sprouting of plants after planting. Results of the current research showed that only the containerized spruce possessed greater durability during shorter storage (approximately 1 month) at these temperatures and, after planting, were able to thrive and grow. Containerized spruce even showed comparable vitality of the fine roots after storage at higher temperatures (from $-3.4{ }^{\circ} \mathrm{C}$ to $-1.7^{\circ} \mathrm{C}$ ). The current result of the inspection of the condition of frozen planting stock suggests that the REL and the restoration of the growth after planting appear to be reliable indicators showing the condition of the planting stock during and after freezing. It is also clear that containerized planting stock is more resistant to lower freezing temperatures than bare-rooted planting stock and that Norway Spruce withstands these temperatures better than European Beech.

The current research showed that the temperature limit for storing of tested plants by freezing is from $-5.6{ }^{\circ} \mathrm{C}$ to $-5.9^{\circ} \mathrm{C}$. The plants stored at this temperature generally showed comparable vitality of fine roots, as when stored at $-3.4^{\circ} \mathrm{C}$ to $-1.7^{\circ} \mathrm{C}$. A slightly increased plant mortality of up to $30 \%$ and a comparable increment with the plants stored at $-3.4^{\circ} \mathrm{C}$ to $-1.7^{\circ} \mathrm{C}$ were recorded, but some containerized beeches and spruces even showed higher increment and lower mortality than those stored at $-3.4^{\circ} \mathrm{C}$ to $-1.7^{\circ} \mathrm{C}$. Mena-Petite et al. [31] explain that the root ball provides protection against desiccation during storage. The unsuitability of storage temperatures below $-5{ }^{\circ} \mathrm{C}$ was then indicated by Camm et al. [1]. Plants tested in this research and stored at approx. $-6^{\circ} \mathrm{C}$ can also be influenced by storage time and the conditions encountered after planting. Bare-rooted and containerized spruce and beech stored at $-5.6^{\circ} \mathrm{C}$ for one month and planted in soil in the tree nursery in the current research, showed zero mortality after planting but after two months of storage and planting in a clearing, their mortality increased to $20-30 \%$.

The main benefit of storage of planting stock at freezing temperatures, according to Rikala [2], is the possible extension of the spring planting season. Frozen plants are, according to the author, extra resistant to drought and cold and, especially in dry conditions, demonstrate better growth than open-storage plants. Jacobs et al. [32] emphasize that plants stored in the freezer have proved to be highly resistant to the damage from spring frosts.

The open-storage method, based on the current results, is suitable for containerized beeches and bare-rooted spruces. Rikala [2] recalls that, in this way, mainly containerized root planting stock is stored. The current results may be affected by the unusually high air temperatures that were measured (without snow cover) during the 2017/2018 winter season [33]. Air temperature and the amount of precipitation during this winter may have greatly influenced the open storage of the planting stock and such negative impact could be mitigated by the overwintering of plants.

The storage of the plants in the current research through the winter in the cave $\left(+2.2^{\circ} \mathrm{C}\right)$, without the protection of the root system (bare-rooted plants) or only covered the root balls with foil (containerized plants), has proven to be inappropriate for overwinter storage of planting stock of both species of trees due to unacceptable mortality after planting. During storage, planting stock was already recorded as having a high REL value (i.e., low vitality of fine roots). This was probably due to a large variation in air temperatures (between $+2{ }^{\circ} \mathrm{C}$ and $+6^{\circ} \mathrm{C}$ ) and a lack of relative humidity $(58-75 \%)$. Wilnen, Vaartaja [8] point out that the storage of plants in non-air-conditioned spaces (i.e., cellars) was only possible with roots stored in moist peat and with high relative humidity. These authors [8] recommended a stable temperature of up to $+6{ }^{\circ} \mathrm{C}$ and a relative humidity of above $80 \%$. The conditions of an air-conditioned warehouse meet these criteria where our tested plants achieved a high vitality of their fine roots (low REL), zero mortality and, 
usually, an increment comparable to that of plants stored at $-3.4^{\circ} \mathrm{C}$ to $-1.7^{\circ} \mathrm{C}$. However, in these conditions, despite fungicide treatment, intensive fungal infestation of spruce was noted, as also Landis et al. [10] point out. Even though the infected plants survived and were able to grow after planting, the fungal infection can cause a higher mortality when storing a larger number of plants. Storage at temperatures of above $0{ }^{\circ} \mathrm{C}$, with a high relative humidity may be an inappropriate way to store evergreen coniferous trees.

\section{Conclusions}

Overwinter storage of planting stock in an air-conditioned storage or freezers, while ensuring optimal conditions, is a safe way to store planting stock over the winter period and, at the same time, facilitates the spring expedition of plants from the nursery by preparing the planting stock. This study has confirmed some information known about overwinter storage of plants, compared its methods and also specified the optimal temperature values and limits which depend on the tree species, the type of planting stock and the length of storage period. From the results obtained from the testing of more treatments of three methods for the storage of both bare-rooted and containerized planting stock of Norway spruce and European beech, we can conclude that:

- Overwinter storage of planting stock is possible within the temperatures range of $-1.7^{\circ} \mathrm{C}$ to $-3.4^{\circ} \mathrm{C}$. After removal from the storage, the plants achieve a high vitality of the fine roots, minimal (sometimes even zero) mortality and a higher increment after planting.

- Air temperatures of $-5.6{ }^{\circ} \mathrm{C}$ to $-5.9{ }^{\circ} \mathrm{C}$ are suitable for short storage (the period tested was 1 month). Two months and longer storage can lead to a slight rise in plant mortality, lower vitality of the fine roots and an increment comparable to that during the storage from $-1.7^{\circ} \mathrm{C}$ to $-3.4^{\circ} \mathrm{C}$.

- After overwinter storage at air temperatures of $-6.6^{\circ} \mathrm{C}$ to $-8.4^{\circ} \mathrm{C}$, the plants show low vitality of the fine roots and unacceptably high mortality. Only some containerized plants (Norway spruce) can be stored in such lower temperatures for a shorter time (the period tested was 1 month). Therefore, the temperature limit for plant storage will be probably affected by the time of storage.

- Storage in an air-conditioned storage $\left(+2{ }^{\circ} \mathrm{C}, 100 \%\right.$ relative humidity $)$ can be recommended for European Beech, but in the case of Norway Spruce, despite fungicide treatment, there is a disproportionate occurrence of fungal infestation.

- Open storage is recommended only in suitable weather conditions with the careful overwintering of plants.

- $\quad$ Plants cannot be stored if the temperature in the storage area varies considerably (tested from $+2{ }^{\circ} \mathrm{C}$ to $+6{ }^{\circ} \mathrm{C}$ ) and if they are not protected against desiccation in the case of low relative humidity (tested $58-75 \%$ ).

- Containerized planting stock is more resistant to low freezing temperatures than bare-rooted planting stock.

- Norway Spruce is more resistant to low freezing temperatures than European Beech.

Author Contributions: P.P., field data harvesting, data analysis and writing-original draft preparation; K.H., field data harvesting and writing —original draft preparation; O.M., conceptualisation, methodology. All authors have read and agreed to the published version of the manuscript.

Funding: This work was funded from the NAZV Grant No. QJ1520080-financial support by the Czech Republic Ministry of Agriculture.

Acknowledgments: We would like to thank the nursery LESCUS Cetkovice, s.r.o. for providing the planting stock that we needed for our research and also for the kind permission to use their premises. We would like to thank Jan Hobl for a review of the English text.

Conflicts of Interest: The authors declare no conflict of interest. 


\section{References}

1. Camm, E.L.; Goetze, D.C.; Silim, S.N.; Lavender, D.P. Cold storage of conifer seedlings: An update from the British Columbia perspective. For. Chron. 1994, 70, 311-316. [CrossRef]

2. Rikala, R. Metsäpuiden Paakkutaimien Kasvatusopas (Container Seedling Growing Manual for Forest Trees); The Finnish Forest Research Institute: Suonenjoki, Finland, 2012; p. 247.

3. Landis, T.; Dumroese, R.K.; Haase, D.L. Seedling Processing, Storage, and Outplanting Agric. Handbk. In The Container Tree Nursery Manual; U.S. Department of Agriculture Forest Service: Washington, DC, USA, 2010; Volume 7, p. 200.

4. Luoranen, J.; Saksa, T.; Lappi, J. Seedling, planting site and weather factors affecting the success of autumn plantings in Norway spruce and Scots pine seedlings. For. Ecol. Manag. 2018, 419-420, 79-90. [CrossRef]

5. Mordas, D.; Wojtkowiak, R.; Wiśniewski, M.; Ratajczak, W. Changes in humidity during outdoor storage of seedlings in styrofoam containers on racks covered with different materials. Acta Sci. Pol. Silvarum Colendarum Ratio Ind. Lignaria 2013, 12, 13-22.

6. Schaberg, P.G.; Hennon, P.E.; D'Amore, D.V.; Hawley, G.J. Influence of simulated snow cover on the cold tolerance and freezing injury of yellow-cedar seedlings. Glob. Chang. Biol. 2008, 14, 1282-1293. [CrossRef]

7. Śliwa, S. Storage of the containerized planting stock in polish forest nurseries. In Manipulace a Skladování Sadebního Materiálu Lesních Dřevin: Handling and Storage of Forest Planting Stock; Houšková, K., Ed.; Mendelova Univerzita v Brně: Brno, Czech Republic, 2015; Volume 5, pp. 24-28.

8. Wilnen, J.; Vaartaja, O. Prevention of injury to tree seedlings during cellar storage. For. Chron 1958, 34, 132-138. [CrossRef]

9. Mandel, R.H. Container seedling handling and storage in the Rocky Mountain and Intermountain regions. In Proceedings of the National Proceedings: Forest and Conservation Nursery Associations-2004, Charleston, SC, USA, 12-15 July 2004; Proceedings RMRS-P-33. USDA Forest Service, Rocky Mountain Research Station: Fort Collins, CO, USA, 2005; pp. 8-9.

10. Landis, T.D.; Luna, T. Harvesting, storing, and shipping. In Nursery Manual for Native Plants: A Guide for Tribal Nurseries; U.S. Department of Agriculture Forest Service: Washington, DC, USA, 2009; pp. 229-245.

11. Kooistra, C.M. Seedling storage and handling in western Canada. In Proceedings of the National Proceedings: Forest and Conservation Nursery Associations-2004, Charleston, SC, USA, 12-15 July 2004; Riley, L.E., Dumroese, R.K., Landis, T.D., Eds.; Proceedings RMRS-P-33 2004. US Department of Agriculture, Forest Service, Rocky Mountain Research Station: Fort Collins, CO, USA, 2005; pp. 15-21.

12. Ritchie, G.A. Container seedling storage and handling in the Pacific Northwest: Answers to some frequently asked questions. In Proceedings of the National Proceedings: Forest and Conservation Nursery Associations-2003, Coeur d'Alene, ID, USA, 9-12 June 2003; Riley, L.E., Dumroese, R.K., Landis, T.D., Eds.; USDA Forest Service Proceedings RMRS-P-33. US Department of Agriculture, Forest Service, Rocky Mountain Research Station: Fort Collins, CO, USA, 2004; pp. 3-7.

13. Luoranen, J.; Riikonen, J.; Rikala, R.; Sutinen, S. Frost hardiness, carbohydrates and bud morphology of Picea abies seedlings after different lengths of freezer storage. Scand. J. For. Res. 2012, 27, 414-419. [CrossRef]

14. Grossnickle, S.C.; South, D.B. Fall acclimation and the lift/store pathway: Effect on reforestation. Open For. Sci. J. 2014, 7, 1-20. [CrossRef]

15. Němec, P. Možnosti dlouhodobého a krátkodobého skladování sadebního materiálu lesních dřevin v klimatizovaných skladech. In Moderní Školkařské Technologie a Jejich Využití v Lesnictvi II; Intenzifikační Opatření v Lesních Školkách: Řečany nad Labem, Czech Republic, 2016.

16. Radoglou, K.; Raftoyannis, Y. The impact of storage, desiccation and planting date on seedling quality and survival of woody plant species. Forestry 2002, 75, 179-190. [CrossRef]

17. Garriou, D.; Girard, S.; Guehl, J.M.; Généré, B. Effect of desiccation during cold storage on planting stock quality and field performance in forest species. Ann. For. Sci. 2002, 57, 101-111. [CrossRef]

18. Vitra, A.; Lenz, A.; Vitasse, Y. Frost hardening and dehardening potential in temperate trees from winter to budburst. New Phytol. 2017, 216, 113-123. [CrossRef] [PubMed]

19. Wong, C.Y.; Gamon, J.A. The photochemical reflectance index provides an optical indicator of spring photosynthetic activation in evergreen conifers. New Phytol. 2015, 206, 196-208. [CrossRef]

20. Bárta, A. Experience with the storage and handling of the forest planting stock in operating conditions of the LESCUS forest nursery Cetkovice, s.r.o. In Manipulace a Skladování Sadebniho Materiálu Lesních Dřevin: Handling and Storage of Forest Planting Stock; Houšková, K., Ed.; Mendelova Univerzita v Brně: Brno, Czech Republic, 2015; Volume 5, pp. 24-28.

21. Bigras, F.S.; Colombo, S.J. (Eds.) Conifer Cold Hardiness; Kluwer: Dordrecht, The Netherlands, 2001; pp. $223-252$.

22. Lindström, A.; Stattin, E.; Gräns, D.; Wallin, E. Storability measures of Norway spruce and Scots pine seedlings and assessment of post-storage vitality by measuring shoot electrolyte leakage. Scand. J. For. Res. 2014, 29, 717-724. [CrossRef]

23. Janda, T.; Majláth, I.; Szalai, G. Interaction of temperature and light in the development of freezing tolerance in plants. J. Plant Growth Regul. 2014, 33, 460-469. [CrossRef]

24. Kozlowski, T.T.; Pallardy, S.G. Acclimation and adaptive responses of woody plants to environmental stresses. Bot. Rev. 2002, 68, 270-334. [CrossRef]

25. Yadav, S.K. Cold stress tolerance mechanisms in plants. Agron. Sustain. Dev. 2010, 30, 515-527. [CrossRef]

26. Solanke, A.U.; Sharma, A.K. Signal transduction during cold stress in plants. Physiol. Mol. Biol. Plants 2008, 14, 69-79. [CrossRef] [PubMed] 
27. Wesoly, W.; Chabowska, A. Winter storage of pedunculate oak (Quercus robur L.) seedlings. Zarzadzanie Ochr. Przyr. Lasach 2016, 10. [CrossRef]

28. Dumroese, R.K.; Barnett, J.P. Container seedling handling and storage in the Southeastern States. In Proceedings of the National Proceedings: Forest and Conservation Nursery Associations-2003, Coeur d'Alene, ID, USA, 9-12 June 2003; Riley, L.E., Dumroese, R.K., Landis, T.D., Eds.; USDA Forest Service Proceedings RMRS-P-33. US Department of Agriculture, Forest Service, Rocky Mountain Research Station: Fort Collins, CO, USA, 2004; pp. 22-25.

29. Repo, T.; Korhonen, A.; Lehto, T.; Silvennoinen, R. Assessment of frost damage in mycorrhizal and non-mycorrhizal roots of Scots pine seedlings using classification analysis of their electrical impedance spectra. Trees 2016, 30, 483-495. [CrossRef]

30. Wang, Y.; Zwiazek, J.J. Physiological characteristics and carbohydrate contents of spring-lifted Picea glauca bareroot seedlings following low-temperature storage. Scand. J. For. Res. 2001, 16, 415-421. [CrossRef]

31. Mena-Petite, A.; Ortega-Lasuen, U.; González-Moro, B.; Lacuesta, M.; Muñoz-Rueda, A. Storage duration and temperature effect on the functional integrity of container and bare-root Pinus radiata D. Don stock types. Trees 2001, 15, 289-296. [CrossRef]

32. Jacobs, D.F.; Wilson, B.C.; Ross-Davis, A.L.; Davis, A.S. Cold hardiness and transplant response of Juglans nigra seedlings subjected to alternative storage regimes. Ann. For. Sci. (EDP Sci.) 2008, 65, 606-613. [CrossRef]

33. Skalak, P.; Stepanek, P.; Zahradnicek, P.; Trnka, M. Extreme Drought of 2018 in the Czech Republic. Geophys. Res. Abstr. 2019, 21, 9-11. 